\title{
Adequacy of Social Services for Persons with Disability of a Second Class City in Negros Occidental
}

\author{
Cherry Belle R. Marcella ${ }^{1}$ and Ma. Dolores J. Nalumen ${ }^{2}$ \\ ${ }^{1}$ City Social Welfare and Development Office, Cadiz City, Negros Occidental, Philippines \\ ${ }^{2}$ University of Negros Occidental-Recoletos, Bacolod City, Philippines
}

\begin{tabular}{l} 
Article history \\
Submitted: 23 October 2020 \\
Revised: 5 November 2020 \\
Accepted: 16 November 2020 \\
\hline Keywords \\
Social Work \\
Social Services \\
Adequacy \\
Persons with Disability \\
Descriptive-Comparative \\
Negros Occidental
\end{tabular}

Article history

Submitted: 23 October 2020

Revised: 5 November 2020

Accepted: 16 November 2020 also explored the challenges faced by the respondents in availing of the social services and their recommendations to overcome those challenges.

Methods. The study used a quantitative research design which employed descriptive and comparative research approaches Using the stratified random sampling, 302 registered PWDs were selected as respondents of the study. A validated and reliability-tested researcher-made survey questionnaire was used to gather the data. Mean, Standard Deviation, frequency count, percentage distribution, Mann Whitney $\mathrm{U}$ test and Kruskal-Wallis $\mathrm{H}$ test were used to analyze the data.

Results. Overall, PWDs assessed the delivery of services provided by the City Social Welfare and Development Office as "adequate" when taken as a whole. PWDs are satisfied with the services under the health, education, livelihood, social aspect and empowerment. PWDs are also most satisfied in the health services. However, they are less likely satisfied with empowerment services. When grouped according to sex, findings showed no significant difference in the extent of adequacy of social services for PWDs. On the other hand, there is a significant difference in the extent of adequacy of social services for PWDs when they are grouped according to age, educational level, and type of disability. Despite the adequate results of the delivery of social services, PWDs revealed that the limited supplies followed by delayed delivery of services and the distance of social agency from their homes were the challenges PWDs encountered when they availed of those services. Thus, PWDs recommended that having an additional budget must be given priority followed by proper information dissemination.

Conclusion. The adequacy of social services provided by the City Social Welfare and Development Office in a second-class city in Negros Occidental showed that PWDs find the programs and services under each element as sufficient. This implies that as a welfare agency, CSWDO fulfilled its obligations specified under the law. However, it can be noted that generally speaking, services made available did not receive a "very adequate" rating from the respondents because of the challenges they have encountered in availing these social services. These difficulties, which could be considered barriers for holistic development, can be attributed to several factors like the limited supplies of materials and equipment needed and the delay in providing social services. These challenges can be used as starting points in determining where improvements should be called for enhancing social services. It is not a surprise that the primary recommendation of PWDs to improve the services is to allow additional budget in their sectoral programs. Proper dissemination of information came second, which means that PWDs have not been well informed about the services that the CSWDO is providing. 
Practical Value of the Paper. The study is beneficial to the CSWDO staff, for it provided them with information on how adequate the social services they are providing. Significantly. it provided the LGU with a basis for formulating more effective ways of providing adequate aid to address the needs of the PWDs towards coming up with an Enhanced Social Services Program, which will be utilized in the local social welfare office and in barangay units.

\section{References}

Asian Development Bank (2018). Inclusive Service Delivery for Persons with Disabilities in Mongolia. Retrieved from doi.org/10.22617/BRF189350

Agbon, A. \& Mina, C. (2017). School Participation of Children with Disability: The Case of San Remigio and Mandaue City, Cebu, Philippines. Philippine Institute for Development Studies, available at https://pidswebs.pids.gov. $\mathrm{ph} / \mathrm{CDN} / \mathrm{PUBLICATIONS/pidsdps1759 \_ rev.pdf}$

Axelsson, C. \& Barrett, D. (2009). Access to Social Services for Persons with Disabilities in the Middle East - Multistakeholder reflections for policy reform. Disability Monitor and Initiative - Middle East, CBM, and Handicap International.

Berhanu, D. S. (2015). Psychosocial challenges of women with disabilities in some selected Districts of Gedeo Zone SNNPR: International Journal of Criminal Justice Sciences, Vol 10, Issue 2, Dilla, Ethiopia.

Mina, C. (2013). Employment of persons with disabilities (PWDs) in the Philippines: The case of Metro Manila and Rosario, Batangas. Philippines Institute for Development Studies. Retrieved from https://pidswebs.pids.gov. $\mathrm{ph} / \mathrm{ris} / \mathrm{dps} /$ pidsdps1313.pdf

Mina, C., and Agbon, A. (2017). School Participation of Children with Disability: The Case of San Remigio and Mandaue City, Cebu, Philippines. Philippines Institute for Development Studies. Discussion paper series no. 2017-59. Retrieved from https://pidswebs.pids.gov.ph/CDN/PUBLICATIONS/pidsdps1759_rev.pdf

Naami, A. \& Mikey-Iddrisu, A. (2013). Empowering Persons with Disabilities to Reduce Poverty: A Case Study of Action on Disability and Development, Ghana. Retrieved from doi:10.4172/2329-9126.1000113

Narayanan, S. (2018). A Study on Challenges Faced by Disabled People at the Workplace in Malaysia. Retrieved from https://www.researchgate.net/publication/326173745_A_STUDY_ON_CHALLENGES_FACED_BY_DISABLED_ PEOPLE_AT_WORKPLACE_IN_MALAYSIA

Rotarou, E. S. \& Sakellariou, D. (2019). Access to health care in an age of austerity: disabled people's unmet needs in Greece. Taylor \& Francis. Retrieved from https://doi.org/10.1080/09581596.2017.1394575

Senghor, D.B., Diop, O. \& Sombie, I. (2017). Analysis of the impact of healthcare support initiatives for physically disabled people on their access to care in the city of Saint-Louis, Senegal. BMC Health Serv Res 17, 695. Retrieved from https://doi.org/10.1186/s12913-017-2644-y

\section{Correspondence:}

Cherry Belle R. Marcella [chebz7.marcella@yahoo.com]

http://orcid.org/0000-0002-1899-9225 